\title{
Acute ethanol exposure inhibits silencing of cerebellar Golgi cell firing induced by granule cell axon input
}

\author{
Paolo Botta, Aya Zucca and C. Fernando Valenzuela* \\ Department of Neurosciences, University of New Mexico Health Sciences Center, Albuquerque, NM, USA
}

\section{Edited by:}

Marisa Roberto, The Scripps Research Institute, USA

\section{Reviewed by:}

Mark S. Brodie, University of Illinois at Chicago, USA

John Woodward, Medical University

of South Carolina, USA

Ronald K. Freund, University of

Colorado Anschutz Medical Campus,

USA

\section{*Correspondence:}

C. Fernando Valenzuela, Department of Neurosciences, University of New Mexico Health Sciences Center, Albuquerque, NM 87131-0001, USA e-mail:FValenzuela@salud.unm.edu
Golgi cells (GoCs) are specialized interneurons that provide inhibitory input to granule cells in the cerebellar cortex. GoCs are pacemaker neurons that spontaneously fire action potentials, triggering spontaneous inhibitory postsynaptic currents in granule cells and also contributing to the generation tonic $\mathrm{GABA}_{A}$ receptor-mediated currents in granule cells. In turn, granule cell axons provide feedback glutamatergic input to GoCs. It has been shown that high frequency stimulation of granule cell axons induces a transient pause in GoC firing in a type 2-metabotropic glutamate receptor (mGluR2)-dependent manner. Here, we investigated the effect ethanol on the pause of GoC firing induced by high frequency stimulation of granule cell axons. GoC electrophysiological recordings were performed in parasagittal cerebellar vermis slices from postnatal day 23 to 26 rats. Loose-patch cell-attached recordings revealed that ethanol $(40 \mathrm{mM})$ reversibly decreases the pause duration. An antagonist of mGluR2 reduced the pause duration but did not affect the effect of ethanol. Whole-cell voltage-clamp recordings showed that currents evoked by an mGluR2 agonist were not significantly affected by ethanol. Perforated-patch experiments in which hyperpolarizing and depolarizing currents were injected into GoCs demonstrated that there is an inverse relationship between spontaneous firing and pause duration. Slight inhibition of the $\mathrm{Na}^{+} / \mathrm{K}^{+}$pump mimicked the effect of ethanol on pause duration. In conclusion, ethanol reduces the granule cell axon-mediated feedback mechanism by reducing the input responsiveness of GoCs. This would result in a transient increase of $\mathrm{GABA}_{A}$ receptor-mediated inhibition of granule cells, limiting information flow at the input stage of the cerebellar cortex.

Keywords: cerebellum, Golgi cell, interneuron, ethanol, metabotropic, glutamate, feedback, GABA

\section{INTRODUCTION}

The cerebellum controls motor coordination, balance, muscle tone, motor learning, and cognition. These functions are mediated, in part, by neurons located in the cerebellar cortex, which receives excitatory input from the somatosensory system and the cerebral cortex (Ito, 2006). These excitatory inputs are relayed by glutamatergic mossy fibers originating in the brain stem and spinal cord. A mossy fiber makes synaptic connections with hundreds of cerebellar granule cells and thousands of these cells provide excitatory input to Purkinje neurons via the ascending portion of their axons as well as the parallel fibers (Figure 1A). The activity of cerebellar granule cells is regulated by inhibitory input provided by a specialized interneuron, the Golgi cell (GoC; Figure 1A). The typical GoC has a large soma $(\sim 20 \mu \mathrm{m})$ with 2-3 long apical dendrites that project into the molecular layer and several short basal dendrites located in the granule cell layer. The GoC axon is extensively ramified, making synaptic contacts with thousands of granule cell and unipolar brush cell dendrites (Ito, 2006; D’Angelo, 2008; Galliano et al., 2010). Studies with mice indicate that a significant portion of GoCs can co-express both GABAergic and glycinergic markers (Simat et al., 2007). However, the inhibitory postsynaptic currents at GoC-granule cell synapses are solely mediated by $\mathrm{GABA}_{\mathrm{A}}$ receptors, whereas those at unipolar brush cells are mediated by both $\mathrm{GABA}_{\mathrm{A}}$ and glycine receptors (Geurts et al., 2003).

GoCs provide both tonic and phasic $\mathrm{GABA}_{\mathrm{A}}$ receptormediated inhibition to cerebellar granule cells. Tonic inhibition is mediated by extrasynaptic $\mathrm{GABA}_{\mathrm{A}}$ receptors containing $\alpha_{6} \beta \delta$ subunits, activated by ambient GABA levels, generated, in part, by accumulation of GABA released from GoCs and perhaps also from lamellar astrocytes under certain experimental conditions (Lee et al., 2010; Diaz et al., 2011, 2013). Phasic inhibition is primarily mediated by synaptic $\mathrm{GABA}_{\mathrm{A}}$ receptors containing $\alpha_{1} \beta \gamma 2$ subunits, activated by evoked or spontaneous action potential-dependent GABA release (Rossi et al., 2003). Evoked GABA release is triggered by mossy fiber or granule cell axon (i.e., both ascending and parallel fiber segments) stimulation of GoCs, whereas spontaneous GABA release is driven by spontaneous action potential firing of GoCs. GoCs display ongoing action potential firing activity at frequencies between $1-10 \mathrm{~Hz}$ in cerebellar slices (Dieudonne, 1998; Carta et al., 2004; Forti et al., 2006; Solinas et al., 2007; Botta et al., 2010), 2-30 Hz in anesthetized rats (Schulman and Bloom, 1981; Vos et al., 1999; Holtzman et al., 2006), $\sim 8 \mathrm{~Hz}$ in awake rats (Huang et al., 2012) 

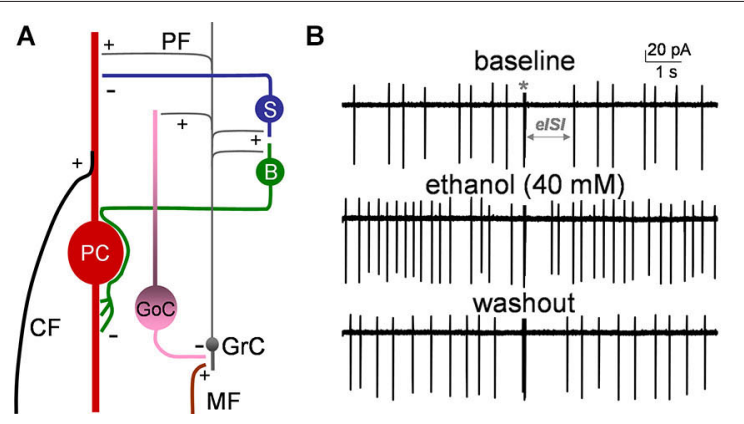

C

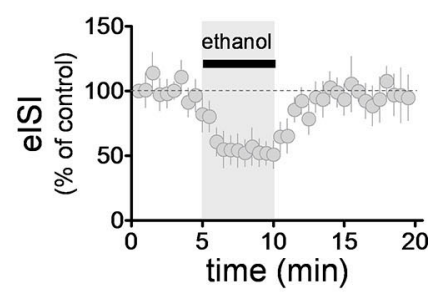

FIGURE 1 | Ethanol reversibly decreased the firing pause in Golgi cells. (A) Schematic representation of the main components of the cerebellar cortex. A mossy fiber (MF) makes a synaptic connection with a granule cell $(\mathrm{GrC})$ dendrite. The granule cell axon (both via the ascending and the parallel fiber (PF) segments), in turn, connects with a Golgi cell (GoC) apical dendrite, providing feedback excitation to the GoC, and driving feedback inhibition of the $\mathrm{GrC}$. Under conditions of burst stimulation, synaptic transmission at $\mathrm{GrC}$ axon-to-GoC dendrite causes a pause in spontaneous action potential firing of GoCs, leading to transient disinhibition of $\mathrm{GrCs}$. Not depicted are the basal dendrites of the GoC or the MF inputs to these dendrites. Also shown are the stellate (S) and basket (B) cells, which are excited by $\mathrm{GrC}$ axons and provide inhibitory input to the Purkinje cell (PC).
The two glutamatergic inputs to the PC (i.e., the climbing fiber, CF, and PF) are also depicted. +, glutamatergic synapse; -, GABAergic synapse. (B) Sample traces corresponding to a loose-patch cell-attached recording from a Golgi cell. The baseline trace illustrates the pause in spontaneous firing of the Golgi cell induced by granule cell axon stimulation with a train of five stimuli ( $50 \mu \mathrm{s}$ duration each) at $100 \mathrm{~Hz}$ (marked with an asterisk). The pause in firing is denoted as the evoked interspike interval (eISI). The middle trace shows that ethanol increased basal firing of the Golgi cell and reduced the duration of the pause. The bottom trace shows that this effect was reversible upon washout. (C) Pooled data from five Golgi cells illustrating the time course of the effect of ethanol on the eISI. Values were normalized with respect to the first $30 \mathrm{~s}$ of recording. and $10-80 \mathrm{~Hz}$ in awake monkeys (Miles et al., 1980). Recent evidence suggests that GoCs form an extensive neuronal network, interconnected via gap junctions, that synchronously oscillates in the $5-30 \mathrm{~Hz}$ range, providing rhythmic inhibition to granule cells and ultimately controlling responsiveness to mossy fiber input (Dugue et al., 2009; Ros et al., 2009; Simões de Souza and De Schutter, 2011).

As mentioned above, granule cell axons provide excitatory input to GoCs and this, in turn, provides feedback inhibition to granule cells, decreasing responsiveness to mossy fiber excitatory input (Ito, 2006; Figure 1A). Importantly, studies suggest that this feedback loop may be transiently inhibited by glutamatergic inputs evoked by some sensory stimuli. Specifically, glutamate release evoked by high frequency stimulation of parallel fibers transiently suppresses GoC firing via activation of type2 metabotropic glutamate receptors (mGluR2; Watanabe and Nakanishi, 2003). These receptors activate $G$ protein-coupled inwardly-rectifying potassium (GIRK) channels, which hyperpolarize the membrane potential of GoCs (Watanabe and Nakanishi, 2003). It is thought that this transient suppression of GoC firing allows some mossy fiber inputs to readily excite granule cells without an opposing influence of phasic $\mathrm{GABA}_{\mathrm{A}}$ receptormediated transmission from GoCs. In vivo studies have shown that GoCs typically respond to brief tactile stimuli by decreasing their spontaneous action potential firing rate, suggesting that this mechanism is physiologically important (Holtzman et al., 2006; Xu and Edgley, 2008).

Studies have shown that acute ethanol exposure increases spontaneous action potential firing of GoCs, resulting in an increase in both phasic and tonic GABAergic input to granule cells (Carta et al., 2004; Hanchar et al., 2005; Botta et al., 2010, 2012; Huang et al., 2012; Diaz et al., 2013). In this study, we investigated if acute ethanol exposure also modulates the transient suppression of GoC firing induced by granule cell axon stimulation.

\section{MATERIALS AND METHODS}

For all the experiments, we used ethanol (95\%, spectrophotometric grade) from Sigma Chemical Co. (St. Louis, MO). (2S)-2-Amino-2-[(1S,2S)-2-carboxycycloprop-1-yl]-3-(xanth-9yl) propanoic acid (LY341495), 6-Imino-3-(4-methoxyphenyl) $-1(6 \mathrm{H})$-pyridazinebutanoic acid hydrobromide (gabazine), [S$\left.\left(\mathrm{R}^{*}, \mathrm{R}^{*}\right)\right]$-[3-[[1-(3,4-Dichlorophenyl)ethyl] amino]-2-hydroxypr opyl](cyclohexylmethyl) phosphinic acid (CGP 54626), 2S, $\left.2^{\prime} \mathrm{R}, 3^{\prime} \mathrm{R}\right)-2-\left(2^{\prime}, 3^{\prime}\right.$-Dicarboxycyclopropyl)glycine (DCG-IV), and DL-2-Amino-5-phosphonopentanoic acid were from TocrisCookson (Ellisville, MO). Tetrodotoxin was from EMD Millipore (Billerica, MA). All other chemicals were from Sigma.

\section{BRAIN SLICE PREPARATION}

All animal procedures were approved by the UNM-Health Sciences Center Institutional Animal Care and Use Committee and conformed to National Institutes of Health Guidelines. Experiments were performed in parasagittal vermis cerebellar slices that were prepared from postnatal day (P) 23-P26 male Sprague-Dawley rats (Harlan, Indianapolis, IN). Animals were euthanized by rapid decapitation under deep anesthesia with ketamine $(250 \mathrm{mg} / \mathrm{kg}$ I.P.) and $200 \mu \mathrm{m}$ thick slices were prepared with a vibrating slicer (Technical Products International, St. Louis, MO). Slices were cut in cold solution containing (in $\mathrm{mM})$ : 220 sucrose, $26 \mathrm{NaHCO}_{3}, 10$ glucose, $6 \mathrm{MgSO}_{4}, 2 \mathrm{KCl}$, $1.25 \mathrm{NaH}_{2} \mathrm{PO}_{4}, 0.2 \mathrm{CaCl}_{2}$ and 0.43 ketamine; this solution was pre-equilibrated with $95 \% \mathrm{O}_{2}$ plus $5 \% \mathrm{CO}_{2}$. Immediately after this procedure, slices were transferred to a chamber containing artificial cerebrospinal fluid (ACSF) and allowed to recover at $35-36^{\circ} \mathrm{C}$ for $35 \mathrm{~min}$, followed by storage at room temperature 
for at least $1.5 \mathrm{~h}$ before the start of recordings. ACSF contained (in mM): $126 \mathrm{NaCl}, 2 \mathrm{KCl}, 1.25 \mathrm{NaH}_{2} \mathrm{PO}_{4}, 1 \mathrm{MgSO}_{4}$, $26 \mathrm{NaHCO}_{3}, 2 \mathrm{CaCl}_{2}$, and 10 glucose equilibrated with $95 \% \mathrm{O}_{2}$ plus $5 \% \mathrm{CO}_{2}$. Slices were transferred to a recording chamber perfused with ACSF at a rate of $2-3 \mathrm{ml} / \mathrm{min}$ and maintained at $32-33^{\circ} \mathrm{C}$.

\section{LOOSE-PATCH CELL-ATTACHED ELECTROPHYSIOLOGICAL RECORDINGS}

Neurons were visualized using infrared-differential interference contrast microscopy and recordings were performed with a Multiclamp 700B amplifier (Molecular Devices, Sunnyvale, CA). GoCs were primarily identified on the basis of their location in the granule cell layer, larger size when compared to granule cells, and the presence of spontaneous action potential firing. Patch pipettes had resistances of 3-5 M $\Omega$. Each slice was exposed once to ethanol and the duration of ethanol exposure was limited to $5 \mathrm{~min}$ to avoid the development of rapid tolerance. The loosepatch cell-attached configuration (seal resistance $=8-30 \mathrm{M} \Omega$ ) was used to record action currents and the firing pause. The patch pipettes were filled with regular ACSF and the holding potential was $0 \mathrm{mV}$; the holding potential in loose-patch cellattached experiments does not significantly affect the GoC resting membrane potential because most of the current generated by the amplifier leaks across the loose seal (Perkins, 2006). The pause in GoC firing was induced with a train of five stimuli ( $50 \mu$ s duration each) at $100 \mathrm{~Hz}$ (train duration approximately $40 \mathrm{~ms}$ ) delivered every $30 \mathrm{~s}$. Stimulation was achieved with a concentric bipolar stimulating electrode placed in the inner half of the molecular layer. The pause length was calculated as the time between the stimulation train and the longest interspike interval (ISI) that was observed after the train (i.e., spikes that occurred soon after the high frequency train were not considered; see Figure 3A below for an example).

\section{WHOLE-CELL PATCH-CLAMP RECORDINGS}

The whole-cell patch-clamp configuration was used to record GIRK channel-mediated currents evoked by the mGluR2 agonist, DCG-IV. The recordings were performed as described in the previous section with the exception that pipettes were filled with an internal solution containing (in mM): $90 \mathrm{KH}_{2} \mathrm{PO}_{4}, 10 \mathrm{KCl}, 102$ [4-(2-hydroxyethyl)piperazin-1-yl] ethanesulfonic acid (HEPES), 10 1,2-bis(o-aminophenoxy)ethane-N,N,N $\mathrm{N}^{\prime}, \mathrm{N}^{\prime}$-tetraacetic acid (BAPTA), $4 \mathrm{MgCl}_{2}, 0.4$ GTP, 2 ATP, and 5 phospho-creatine (pH 7.4 with $\mathrm{KOH}$ ) (Watanabe and Nakanishi, 2003). The membrane potential was held at $-70 \mathrm{mV}$. The ACSF contained antagonists of $\mathrm{GABA}_{\mathrm{A}}$ receptors (gabazine, $25 \mu \mathrm{M}$ ), $\mathrm{GABA}_{\mathrm{B}}$ receptors ([S-( $\left.\left.\mathrm{R}^{\star}, \mathrm{R}^{\star}\right)\right]$-[3-[[1-(3,4-Dichlorophenyl)ethyl] amino]-2-hydro xypropyl] (cyclohexylmethyl) phosphinic acid; CGP 54626, $10 \mu \mathrm{M}$ ), glycine receptors (strychinine, $1 \mu \mathrm{M}$ ), $\mathrm{Na}^{+}$channels (tetrodotoxin, $1 \mu \mathrm{M}$ ), ionotropic glutamate receptors (kynurenic acid, $1 \mathrm{mM}$ ), and NMDA receptors (DL-2-Amino-5-phos phonopentanoic acid, $50 \mu \mathrm{M})$. DCG-IV $(10 \mu \mathrm{M})$ was applied in the bath for $30 \mathrm{~s}$. After a steady-state current was observed, the mGluR2 antagonist, LY341495 $(0.5 \mu \mathrm{M})$, was bath-applied for 2-3 min to block the response. Currents were evoked every $10-12 \mathrm{~min}$.

\section{PERFORATED-PATCH ELECTROPHYSIOLOGICAL RECORDINGS}

The perforated-patch configuration was used to further study the effect of ethanol on the firing pause and to characterize the effect of current injection on firing frequency and pause. An amphotericin-B stock solution was made fresh daily ( $2 \mathrm{mg} / \mathrm{ml}$ in dimethylsulfoxide). The stock solution was sonicated for $\sim 15 \mathrm{~min}$, then continuously vortexed at a low speed for the duration of the recording session. The microelectrode tips were prefilled with internal solution containing (in $\mathrm{mM}$ ): $135 \mathrm{~K}$-gluconate, $5 \mathrm{KCl}, 10 \mathrm{HEPES}, 0.2$ Ethylene glycol-bis(2aminoethylether)-N,N,N' $\mathrm{N}^{\prime}$-tetraacetic acid (EGTA), $4.6 \mathrm{MgCl}_{2}$, $0.1 \mathrm{CaCl}_{2}, 4 \mathrm{Na}_{2}$-ATP and 0.4 Na-GTP (pH 7.35 adjusted with $\mathrm{KOH})$ and then backfilled with the same internal solution containing $10 \mu \mathrm{g} / \mathrm{ml}$ of amphotericin-B. The access resistance was used to monitor the progression of perforation, which was considered complete when it was between 40-80 M $\Omega$.

Recordings were performed in the current-clamp mode and currents were injected as indicated. The firing pause was induced as described in the previous section.

\section{DATA ANALYSES}

Data were filtered at $2 \mathrm{kHz}$ and acquired at $5-50 \mathrm{kHz}$ with a Digidata 1322A digitizer and pClamp-9 (Molecular Devices, Sunnyvale, CA). Data were analyzed with Clampfit-9 (Molecular Devices) and MiniAnalysis-6.0.3. (Synaptosoft, Decatur, GA). Data were statistically analyzed with Prizm version 4 or 5 (GraphPad, San Diego, CA) and are presented as mean \pm SEM. To test for normal distribution, data were initially analyzed with the Pearson omnibus normality test. If data followed a normal distribution, these were analyzed using parametric tests. If this was not the case, then non-parametric tests were used. The unit of determination was defined as a slice.

\section{RESULTS \\ ETHANOL REVERSIBLY DECREASES THE DURATION OF THE FIRING PAUSE}

We initially evaluated the effect of ethanol on the firing pause using the loose-patch cell-attached configuration. The pause in spontaneous GoC firing (denoted as the evoked inter-spike interval, eISI) was elicited by a train of high frequency stimulation as described in Section Loose-patch Cell-attached Electrophysiological Recordings. The pause length was calculated as described in Section Loose-patch Cell-attached Electrophysiological Recordings. The high frequency stimulation train elicited an eISI of $2.4 \pm$ $0.6 \mathrm{~s}$ ( $n=5$; see Figure $1 \mathbf{B}$ for sample trace). Application of ethanol $(40 \mathrm{mM})$ significantly decreased the eISI (Figures 1B-C; average of $5 \mathrm{~min}$ baseline eISI $=99 \pm 8.4 \%$; average of $5 \mathrm{~min}$ ethanol eISI $=53.4 \pm 11.4 \%$; paired student $t$-test, $t=6.25, d f=$ $4, p=0.003 ; n=5$ ). In agreement with previous reports (Carta et al., 2004; Botta et al., 2010, 2012), ethanol also increased the GoC firing frequency by $1.2 \pm 0.2 \mathrm{~Hz}$ (one sample $t$-test vs. $0, t=$ 6.6, $d f=4, p=0.002 ; n=5$ ).

As a control, we assessed the effect of ethanol on the changes in GoC excitability elicited by the train of high frequency stimulation. The latency was calculated as the time between the stimulus artifact and the sodium current peak (Figure 2A). The precision calculated as the standard deviation of the latency (Figure 2A). 


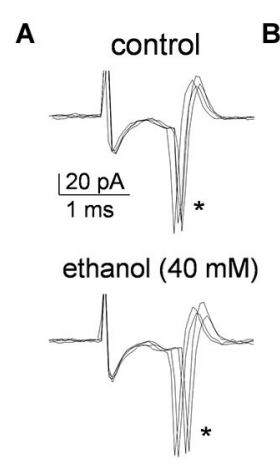

FIGURE 2 | Ethanol did not significantly affect the characteristics of the action currents evoked in Golgi cells by high frequency stimulation of granule cell axons. (A) Sample traces corresponding to a loose-patch cell-attached recording from a Golgi cell illustrating the action currents evoked by the first stimulus (marked with an asterisk) of the five stimuli train (50 $\mu \mathrm{s}$

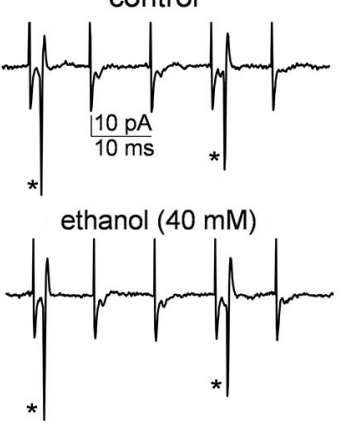

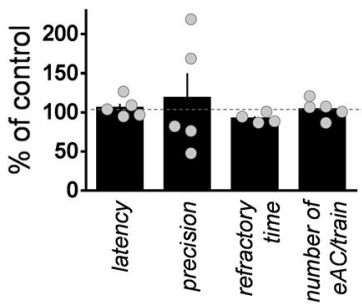

The refractory time was calculated as the time between the first two action currents evoked by the train of high frequency stimulation (Figure 2B). The average number of action currents triggered by the train of 5 stimuli was $2.3 \pm 0.6(n=5$; Figure 2B). Figure $2 \mathrm{C}$ shows that ethanol did not change the latency (one sample $t$-test vs. $100, t=0.95, d f=4, p=0.39 ; n=5$ ), precision (one sample $t$-test vs. 100, $t=0.55, d f=4, p=0.6 ; n=5$ ), refractory time (one sample $t$-test vs. $100, t=2.57, d f=3, p=$ $0.08 ; n=4$ ), or number of evoked action currents elicited by the train of high frequency stimulation (one sample $t$-test vs. 100, $t=$ $0.65, d f=4, p=0.54 ; n=5)$.

\section{ETHANOL REDUCES THE FIRING PAUSE INDEPENDENTLY OF mGluR2 RECEPTORS}

We evaluated the effect of ethanol on the firing pause in presence of a saturating concentration of the mGluR2 antagonist, LY341495 $(1 \mu \mathrm{M})$. These experiments were also performed in the loose-patch cell-attached configuration. LY341495 did not significantly affect baseline firing of GoCs $(109.5 \pm 8.4 \%$ of control; one sample $t$-test vs. $100, t=1.128, d f=8, p=0.29$; $n=9$; see Figure 3A for sample traces). However, it significantly decreased the duration of the firing pause (Figure 3B; average of 5 min baseline eISI $=99.7 \pm 9 \%$; average of $10 \mathrm{~min}$ LY341495 eISI $=76.6 \pm 6.2 \%$; paired student $t$-test, $t=7.73, d f=4$, $p=0.0015 ; n=5)$. In presence of LY341495, ethanol $(40 \mathrm{mM})$ decreased the firing pause to a similar extent as in the absence of this agent (Figure 3B; average of $10 \mathrm{~min}$ LY341495 eISI = $76.6 \pm 6.2 \%$; average of 5 min ethanol eISI $=38.7 \pm 8.1 \%$; paired student $t$-test, $t=13.95, d f=4, p=0.0002$; the eISI in presence of ethanol was $48.2 \pm 6.8 \%$ of the eISI in presence of LY34195; $n=$ 5; compare with Figure 1B).

We directly assessed the effect of ethanol on GIRK currents evoked by mGluR2 stimulation. These currents were evoked by a $30 \mathrm{~s}$ bath application of the selective mGluR2 agonist, DCGIV $(10 \mu \mathrm{M})$, followed by application of the mGluR2 antagonist, LY341495 $(0.5 \mu \mathrm{M})$ to block the responses (Figure 4A). The effect of acute exposure to $40 \mathrm{mM}$ ethanol on these currents was tested in seven GoCs. Ethanol reversibly increased the DCG-IV-evoked duration each at $100 \mathrm{~Hz}$ ) in the absence and presence of $40 \mathrm{mM}$ ethanol. (B) Same as in A but at a more compressed time scale. Note the two action currents (indicated by the asterisks) triggered by the five stimuli train. (C) Summary graph illustrating the lack of effect of ethanol on latency, precision, refractory time, and number of evoked action currents (eAC) per train $(n=4-5)$.

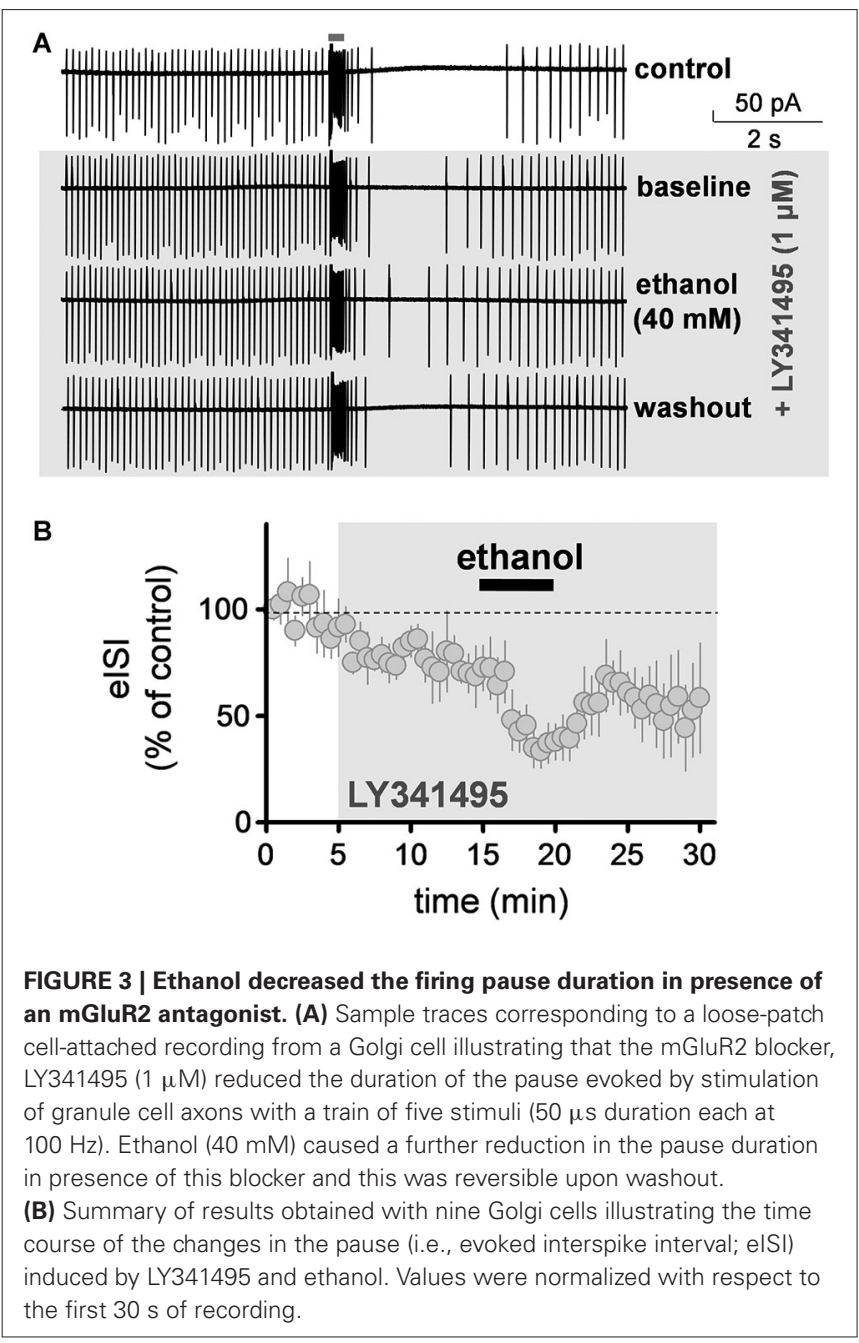

current in three GoCs and had no effect in the other four GoCs (Figures 4A, B). On average, the DCG-IV-evoked current was 130 $\pm 21 \%$ of the average of control and washout responses (Wilcoxon 


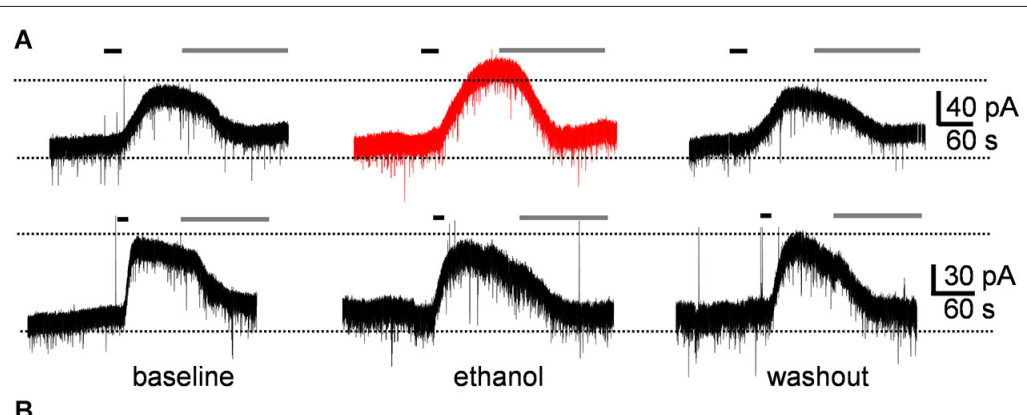

B

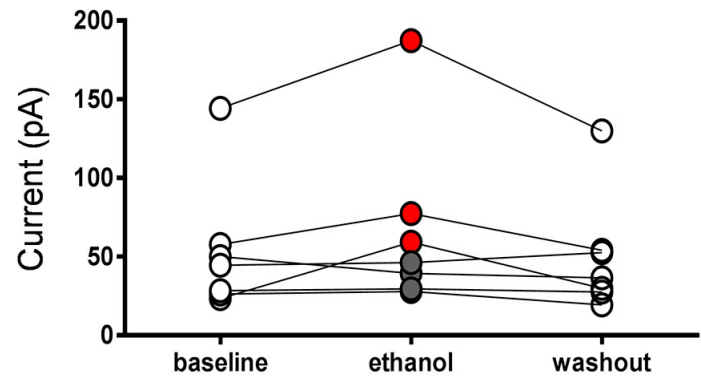

FIGURE 4 | Currents evoked by the mGluR2 agonist, DCG-IV, were not significantly affected by ethanol. (A) Sample traces corresponding to a whole-cell voltage-clamp recording from a Golgi cell illustrating the outward currents evoked by a $30 \mathrm{~s}$ bath application of DCG-IV (10 $\mu \mathrm{M}$; black line). Subsequent application of LY341495 (0.5 $\mu \mathrm{M}$; gray line) blocked the DCG-IV-evoked currents. Currents were evoked at 10-12 min intervals. The top trace corresponds to a $\mathrm{GoC}$ recording where ethanol reversibly potentiated the DCG-IV-evoked current and the lower trace to a recording where ethanol had no effect. (B) Graph summarizing the results obtained in seven Golgi cell recordings, illustrating that ethanol potentiated DCG-IV-evoked currents in three cells (red circles) and did not change them in four cells (gray circles). On average, the DCG-IV-evoked currents in presence of ethanol were $130 \pm 21 \%$ with respect to the average of baseline and washout responses. signed rank test vs. theoretical median of 100; sum of signed ranks $(\mathrm{W})=20$, sum of positive ranks $=24$, sum of negative ranks $=-4$; $p=0.10 ; n=7)$.

\section{ETHANOL REDUCES THE FIRING PAUSE BY DEPOLARIZING THE MEMBRANE POTENTIAL AND INCREASING ACTION POTENTIAL FIRING OF GOLGI CELLS (GoCs)}

We tested the impact of current injection on the firing pause using the perforated-patch current-clamp configuration. Figure 5A shows that injection of depolarizing current $(20 \mathrm{pA})$ both increased the action potential firing frequency and reduced the duration of the pause. Conversely, injection of hyperpolarizing current $(-10 \mathrm{pA})$ both reduced GoC firing and increased the duration of the pause. Figure 5B shows that there is an inverse relationship between the impact of current injection on firing frequency and pause duration.

We have previously shown that slight inhibition of the $\mathrm{Na}^{+} / \mathrm{K}^{+}$ pump with a low concentration of ouabain $(0.1 \mu \mathrm{M})$, mimics the effect of $40 \mathrm{mM}$ ethanol on the membrane potential and spontaneous action potential firing of GoCs (Botta et al., 2010). Therefore, we tested whether this agent could also mimic ethanol's effect on the firing pause (Figure 6). These experiments were performed in the loose-seal cell-attached configuration. In agreement with our previous findings (Botta et al., 2010), application of ouabain $(0.1 \mu \mathrm{M})$ increased the firing frequency by $0.8 \pm 0.2 \mathrm{~Hz}$ (Figure 6A; one sample $t$-test vs. $0, t=3.97, d f=12, p=0.002 ; n=$ 13). In addition, ouabain significantly decreased the firing pause (Figure 6B; baseline eISI $=2.38 \pm 0.22$ s; ouabain eISI $=1.37 \pm$
$0.28 \mathrm{~s}$; paired student $t$-test, $t=3.45, d f=12, p=0.005 ; n=13)$. In agreement with our previous report (Botta et al., 2010), the effect of ouabain was irreversible, as expected from the high affinity of this agent for the $\mathrm{Na}^{+} / \mathrm{K}^{+}$pump.

\section{DISCUSSION}

Studies from multiple laboratories indicate that GoCs are important targets of ethanol. Acute ethanol exposure depolarizes the membrane potential and increases spontaneous action potential firing in these cells (Freund et al., 1993; Carta et al., 2004; Botta et al., 2010, 2012; Huang et al., 2012). Results of electrophysiological and/or computer modeling experiments suggest that the mechanism responsible for this effect involves, at least in part, ethanol-induced inhibition of the $\mathrm{Na}^{+/} \mathrm{K}^{+}$pump and perhaps also a quinidine-sensitive $\mathrm{K}^{+}$channel (Botta et al., 2010, 2012). A recent study suggests that ethanol-induced inhibition of neuronal nitric oxide synthase activity in GoCs also contributes to the mechanism of action of ethanol (Kaplan et al., 2013). The ethanol-induced increase of GoC excitability ultimately results in an increase in phasic and tonic $\mathrm{GABA}_{\mathrm{A}}$ receptor-mediated currents in granule cells (Carta et al., 2004; Botta et al., 2010, 2012; Diaz et al., 2013; Kaplan et al., 2013). A recent study suggests that ethanol acts via an alternative mechanism where potentiation of $\delta$ subunit-containing extrasynaptic $\mathrm{GABA}_{\mathrm{A}}$ receptors in granule cells leads to an increase in glutamatergic synaptic transmission in GoCs, indirectly leading to an increase in spontaneous action potential firing of these cells (Santhakumar et al., 2013). The increase in both phasic and tonic $\mathrm{GABA}_{\mathrm{A}}$ receptor-mediated 


\section{A}

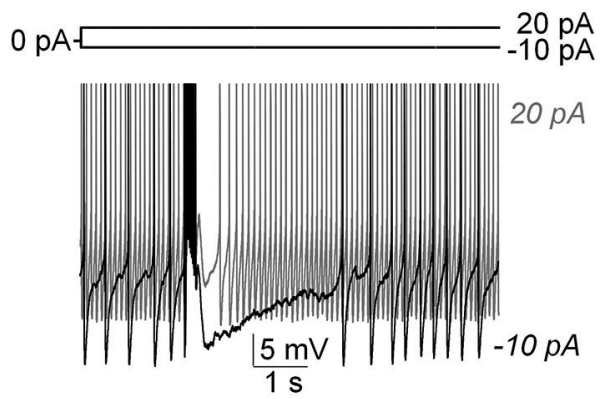

B

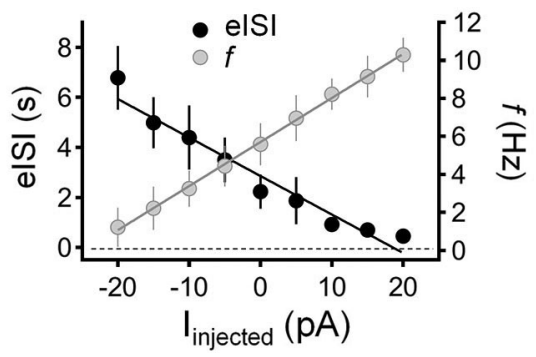

FIGURE 5 | Injection of hyperpolarizing or depolarizing current induced reciprocal changes in Golgi cell firing frequency and pause duration. (A) Sample traces corresponding to perforated-patch current-clamp recordings from a Golgi cell illustrating the effect of hyperpolarizing current injection (-10 pA; black trace) and depolarizing current injection (20 pA, gray trace) on spontaneous firing frequency and pause duration. The pause was induced with a train of five stimuli $(50 \mu \mathrm{s}$ duration each at $100 \mathrm{~Hz})$. (B)

Summary of results obtained in recordings from 9 Golgi cells illustrating the inverse relationship between changes in firing frequency ( $f$, gray circles) and pause duration (evoked interspike interval; elSI, black circles) in response to current injection (linjected).

inhibition in granule cells is thought to be one of the mechanisms explaining the findings of in vivo electrophysiological recordings demonstrating a reduction in responsiveness of granule cells to mossy fiber inputs during acute exposure to ethanol (Huang and Huang, 2007).

Here, we report a novel effect of ethanol that could further limit the responsiveness of granule cells to incoming information transmitted by mossy fibers. We found that ethanol suppresses the pause in GoC firing triggered by high frequency stimulation of granule cell axons. This pause transiently suppresses spontaneous GoC firing, temporarily decreasing synaptic transmission at GoCgranule cell synapses (and perhaps also a portion of currents mediated by extrasynaptic $\mathrm{GABA}_{\mathrm{A}}$ receptors), allowing strong mossy fiber inputs to more effectively excite granule cells, which then relay the signal to Purkinje cells via the parallel fibers and ascending axons (Figure 1A). Granule cells are thought to function as a high signal-to noise-filter because these cells display low levels of spontaneous firing activity as a consequence of the strong $\mathrm{GABA}_{\mathrm{A}}$ receptor-mediated phasic and tonic inhibitory inputs (Chadderton et al., 2004). Incoming mossy fiber burst activity has been shown to effectively excite granule cells and this may facilitate the transmission of subsequent stimuli via transient inhibition of spontaneous GoC firing (Chadderton et al., 2004). Ultimately, the ethanol-induced reduction in the duration of the $\mathrm{GoC}$ pause is expected to result in increased filtering of mossy

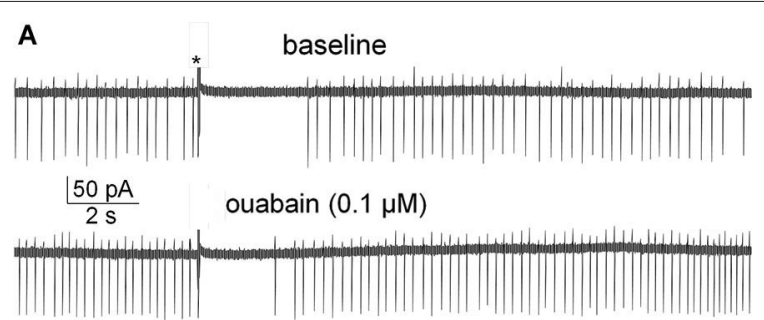

B

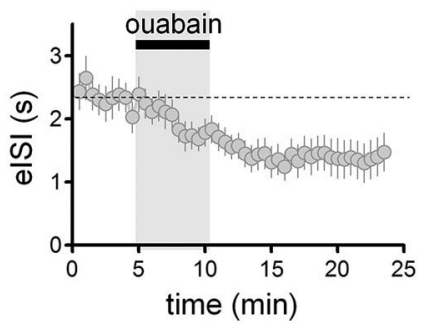

FIGURE 6 | Partial inhibition of the $\mathrm{Na}^{+} / \mathrm{K}^{+}$pump with ouabain mimicked the effect of ethanol on the firing pause of Golgi cells. (A) Sample traces corresponding to a loose-patch cell-attached recording from a Golgi cell. The baseline trace illustrates the pause in spontaneous firing of the Golgi cell induced by granule cell axon stimulation with a train of five stimuli (50 $\mu$ s duration each at $100 \mathrm{~Hz}$; marked with an asterisk). The lower trace shows that a submaximal concentration of the inhibitor of the $\mathrm{Na}^{+} / \mathrm{K}^{+}$ pump, ouabain $(0.1 \mu \mathrm{M})$, increased basal firing of the Golgi cell and reduced the duration of the pause. (B) Pooled data from 13 Golgi cells illustrating the time course of the effect of ouabain on the pause duration (evoked interspike interval; elSI).

fiber inputs at the gateway of information into the cerebellar cortex. As mentioned above, in vivo studies have shown that GoC firing decreases in response to sensory inputs from the periphery and it would be interesting to determine whether this effect is reduced by acute ethanol exposure (Holtzman et al., 2006).

Given that mGluR2 has been shown to play a central role in the mechanism by which parallel fiber input induces the pause in $\mathrm{GoC}$ firing (Watanabe and Nakanishi, 2003), we evaluated the potential involvement of this receptor in the action of ethanol. Using juvenile (P14-P18) transgenic mice expressing the fusion protein of human interleukin-2 receptor subunit and GFP in GoCs, Watanabe and Nakanishi (2003) provided evidence suggesting that mGluR2 are primary mediators of the pause in GoC firing. In P23-P26 rats, we found that the mGluR2 antagonist, LY341495, only partially reduced the $\mathrm{GoC}$ firing pause. This is unlikely due to incomplete blockade of the receptor by LY341495 because we used a saturating concentration $(1 \mu \mathrm{M})$; the IC50 of this agent for mGluR2 was reported to be near $20 \mathrm{nM}$ (Kingston et al., 1998). Moreover, Watanabe and Nakanishi (2003) reported that a $0.5 \mu \mathrm{M}$ concentration of this agent completely blocks mGluR2mediated currents in GoCs of these mice and we also found near complete block in rat slices. In agreement with these findings, we found that $0.5 \mu \mathrm{M}$ LY341495 completely blocked the DCG-IVevoked currents under our experimental conditions. Therefore, it is possible that the mechanism of the GoC pause induction differs between Sprague-Dawley rats and the transgenic mice used by Watanabe and Nakanishi (2003), involving other players besides the mGluR2 in GoCs from Sprague-Dawley rats. 
Two pieces of evidence suggest that changes in mGluR2 function do not play a role in the mechanism of action of ethanol. First, ethanol reduced the GoC pause to a similar extent in the absence and presence of LY341495. Second, ethanol did not have a significant effect on DCG-IV-evoked currents in GoCs. Based on studies indicating that ethanol potentiates GIRK channel function (Kobayashi et al., 1999; Lewohl et al., 1999; Aryal et al., 2009), it would have been expected for it to enhance DCG-IV-evoked currents. However, this would have resulted in lengthening of the pause. Although we observed potentiation of DCG-IV-evoked currents in some GoCs, these were not affected in most recordings. The reasons for the lack of sensitivity of DCG-IV-evoked currents to ethanol in GoCs are unknown but could involve differences in the characteristics of GIRK channels expressed in GoCs vs. those expressed in other neuronal populations (e.g., posttranslational modifications and association with other proteins). Taken together, these findings suggest that ethanol reduces the duration of the GoC pause by a different mechanism that does not involve modulation of mGluR2 or mGluR2-coupled GIRK channels. However, it should be emphasized that the effect of ethanol on the function of mGluR2 and GIRK channels in GoCs should be further characterized. For instance, it is possible that higher concentrations of ethanol more consistently potentiate mGluR2-evoked GIRK currents. It will also be interesting to assess the effect of ethanol on mGluR2-evoked GIRK currents elicited by release of glutamate from granule cell axons.

A novel finding of our study is that the GoC pause can be regulated by changes in the membrane potential and/or action potential firing frequency. We found that injection of depolarizing current caused a decrease in pause duration and injection of hyperpolarizing current increased the pause duration. This effect could be caused, in part, by changes in the function of receptors and/or channels involved in pause generation triggered by changes in the membrane potential. Another possibility is that increases in spontaneous action potential firing results in changes in $\left[\mathrm{Ca}^{2+}\right]_{i}$ and other intracellular messengers, ultimately resulting in alterations in the receptors and/or channels involved in the generation of the pause. Clearly, the mechanisms responsible for this phenomenon require further investigation. Nevertheless, it is possible that both the ethanol-induced depolarization of the membrane potential and the action potential firing increase contribute to the mechanism by which ethanol reduces the firing pause. In support of this possibility is our finding that a submaximal concentration of ouabain, which we previously demonstrated to cause a similar change to that of ethanol in the membrane potential and firing frequency of GoCs (Botta et al., 2010), mimicked the effect of ethanol on the GoC pause. This finding suggests that ethanol acts, at least in part, by inhibiting the $\mathrm{Na}^{+} / \mathrm{K}^{+}$pump in GoCs. It should be emphasized that we previously demonstrated that acute ethanol exposure increases GoC firing in a dose-dependent manner, producing significant effects at concentrations of 20, 40, and $80 \mathrm{mM}$ (Botta et al., 2010). Therefore, other concentrations of ethanol (i.e., 20 and $80 \mathrm{mM}$ ) are expected to inhibit the GoC pause in addition to the $40 \mathrm{mM}$ concentration tested in this study.

In conclusion, we have identified a novel effect of ethanol on GoC physiology that involves a reduction in a feedback mechanism that normally results in a transient decrease of $\mathrm{GABA}_{\mathrm{A}}$ receptor-mediated inhibition of granule cells. This effect may contribute to the decrease in granule cell responsiveness to mossy fiber input that is observed during acute ethanol exposure (Huang and Huang, 2007). Together with other effects of acute ethanol exposure on several cellular components of cerebellar cortical circuits (Botta et al., 2007; Valenzuela et al., 2010), this effect may contribute to produce the motor and cognitive alterations that are associated with acute ethanol intoxication. It was recently shown that the mGluR2-mediated hyperpolarization of the membrane potential can, under some conditions, trigger a rebound long-term increase in the frequency of spontaneous action potential firing in GoCs (Hull et al., 2013). Future studies should examine whether this firing rate plasticity mechanism is also impaired by ethanol.

\section{AUTHOR CONTRIBUTIONS}

Paolo Botta and C. Fernando Valenzuela designed experiments, analyzed data and prepared the manuscript. Paolo Botta and Aya Zucca conducted the experiments.

\section{ACKNOWLEDGMENTS}

Supported by National Institutes of Health Grant AA014973.

\section{REFERENCES}

Aryal, P., Dvir, H., Choe, S., and Slesinger, P. A. (2009). A discrete alcohol pocket involved in GIRK channel activation. Nat. Neurosci. 12, 988-995. doi: 10. 1038/nn.2358

Botta, P., De Souza, F. M., Sangrey, T., De Schutter, E., and Valenzuela, C. F. (2010). Alcohol excites cerebellar Golgi cells by inhibiting the $\mathrm{Na}+\mathrm{K}+$ ATPase. Neuropsychopharmacology 35, 1984-1996. doi: 10.1038/npp.2010.76

Botta, P., Radcliffe, R. A., Carta, M., Mameli, M., Daly, E., Floyd, K. L., et al. (2007). Modulation of GABA(A) receptors in cerebellar granule neurons by ethanol: a review of genetic and electrophysiological studies. Alcohol 41, 187-199. doi: 10. 1016/j.alcohol.2007.04.004

Botta, P., Simoes De Souza, F. M., Sangrey, T., De Schutter, E., and Valenzuela, C. F. (2012). Excitation of rat cerebellar Golgi cells by ethanol: further characterization of the mechanism. Alcohol. Clin. Exp. Res. 36, 616-624. doi: 10.1111/j. 1530-0277.2011.01658.x

Carta, M., Mameli, M., and Valenzuela, C. F. (2004). Alcohol enhances GABAergic transmission to cerebellar granule cells via an increase in Golgi cell excitability. J. Neurosci. 24, 3746-3751. doi: 10.1523/jneurosci.0067-04.2004

Chadderton, P., Margrie, T. W., and Hausser, M. (2004). Integration of quanta in cerebellar granule cells during sensory processing. Nature 428, 856-860. doi: 10 . 1038/nature02442

D’Angelo, E. (2008). The critical role of Golgi cells in regulating spatio-temporal integration and plasticity at the cerebellum input stage. Front. Neurosci. 2:8. doi: 10.3389/neuro.01.008.2008

Diaz, M. R., Wadleigh, A., Hughes, B. A., Woodward, J. J., and Valenzuela, C. F. (2011). Bestrophin 1 channels are insensitive to ethanol and do not mediate tonic GABAergic currents in cerebellar granule cells. Front. Neurosci. 5:148. doi: 10. 3389/fnins.2011.00148

Diaz, M. R., Wadleigh, A., Kumar, S., De Schutter, E., and Valenzuela, C. F. (2013). $\mathrm{Na}+/ \mathrm{K}+$-ATPase inhibition partially mimics the ethanol-induced increase of the Golgi cell-dependent component of the tonic GABAergic current in rat cerebellar granule cells. PLoS One 8:e55673. doi: 10.1371/journal.pone.0055673

Dieudonne, S. (1998). Submillisecond kinetics and low efficacy of parallel fibreGolgi cell synaptic currents in the rat cerebellum. J. Physiol. 510(Pt. 3), 845-866. doi: 10.1111/j.1469-7793.1998.845bj.x

Dugue, G. P., Brunel, N., Hakim, V., Schwartz, E., Chat, M., Levesque, M., et al. (2009). Electrical coupling mediates tunable low-frequency oscillations and resonance in the cerebellar Golgi cell network. Neuron 61, 126-139. doi: 10. 1016/j.neuron.2008.11.028 
Forti, L., Cesana, E., Mapelli, J., and D'angelo, E. (2006). Ionic mechanisms of autorhythmic firing in rat cerebellar Golgi cells. J. Physiol. 574, 711-729. doi: 10. 1113/jphysiol.2006.110858

Freund, R. K., Wang, Y., and Palmer, M. R. (1993). Differential effects of ethanol on the firing rates of Golgi-like neurons and Purkinje neurons in cerebellar slices in vitro. Neurosci. Lett. 164, 9-12. doi: 10.1016/0304-3940(93)90844-b

Galliano, E., Mazzarello, P., and D'angelo, E. (2010). Discovery and rediscoveries of Golgi cells. J. Physiol. 588, 3639-3655. doi: 10.1113/jphysiol.2010.189605

Geurts, F. J., De Schutter, E., and Dieudonne, S. (2003). Unraveling the cerebellar cortex: cytology and cellular physiology of large-sized interneurons in the granular layer. Cerebellum 2, 290-299. doi: 10.1080/14734220310011948

Hanchar, H. J., Dodson, P. D., Olsen, R. W., Otis, T. S., and Wallner, M. (2005). Alcohol-induced motor impairment caused by increased extrasynaptic GABA(A) receptor activity. Nat. Neurosci. 8, 339-345. doi: 10.1038/nn1398

Holtzman, T., Rajapaksa, T., Mostofi, A., and Edgley, S. A. (2006). Different responses of rat cerebellar Purkinje cells and Golgi cells evoked by widespread convergent sensory inputs. J. Physiol. 574, 491-507. doi: 10.1113/jphysiol.2006. 108282

Huang, C. M., and Huang, R. H. (2007). Ethanol inhibits the sensory responses of cerebellar granule cells in anesthetized cats. Alcohol. Clin. Exp. Res. 31, 336-344. doi: 10.1111/j.1530-0277.2006.00309.x

Huang, J. J., Yen, C. T., Tsai, M. L., Valenzuela, C. F., and Huang, C. (2012). Acute ethanol exposure increases firing and induces oscillations in cerebellar Golgi cells of freely moving rats. Alcohol. Clin. Exp. Res. 36, 2110-2116. doi: 10.1111/j. 1530-0277.2012.01818.x

Hull, C. A., Chu, Y., Thanawala, M., and Regehr, W. G. (2013). Hyperpolarization induces a long-term increase in the spontaneous firing rate of cerebellar Golgi cells. J. Neurosci. 33, 5895-5902. doi: 10.1523/JNEUROSCI.4052-12.2013

Ito, M. (2006). Cerebellar circuitry as a neuronal machine. Prog. Neurobiol. 78, 272 303. doi: 10.1016/j.pneurobio.2006.02.006

Kaplan, J. S., Mohr, C., and Rossi, D. J. (2013). Opposite actions of alcohol on tonic GABAA receptor currents mediated by nNOS and PKC activity. Nat. Neurosci. 16, 1783-1793. doi: 10.1038/nn.3559

Kingston, A. E., Ornstein, P. L., Wright, R. A., Johnson, B. G., Mayne, N. G., Burnett, J. P., et al. (1998). LY341495 is a nanomolar potent and selective antagonist of group II metabotropic glutamate receptors. Neuropharmacology 37, 1-12. doi: 10.1016/s0028-3908(97)00191-3

Kobayashi, T., Ikeda, K., Kojima, H., Niki, H., Yano, R., Yoshioka, T., et al. (1999). Ethanol opens G-protein-activated inwardly rectifying K+ channels. Nat. Neurosci. 2, 1091-1097. doi: 10.1038/16019

Lee, S., Yoon, B. E., Berglund, K., Oh, S. J., Park, H., Shin, H. S., et al. (2010). Channel-mediated tonic GABA release from glia. Science 330, 790-796. doi: 10. 1126/science.1184334

Lewohl, J. M., Wilson, W. R., Mayfield, R. D., Brozowski, S. J., Morrisett, R. A., and Harris, R. A. (1999). G-protein-coupled inwardly rectifying potassium channels are targets of alcohol action. Nat. Neurosci. 2, 1084-1090. doi: 10.1038/ 16012

Miles, F. A., Fuller, J. H., Braitman, D. J., and Dow, B. M. (1980). Long-term adaptive changes in primate vestibuloocular reflex. III. Electrophysiological observations in flocculus of normal monkeys. J. Neurophysiol. 43, 1437-1476.

Perkins, K. L. (2006). Cell-attached voltage-clamp and current-clamp recording and stimulation techniques in brain slices. J. Neurosci. Methods 154, 1-18. doi: 10.1016/j.jneumeth.2006.02.010
Ros, H., Sachdev, R. N., Yu, Y., Sestan, N., and Mccormick, D. A. (2009). Neocortical networks entrain neuronal circuits in cerebellar cortex. J. Neurosci. 29, 1030910320. doi: 10.1523/JNEUROSCI.2327-09.2009

Rossi, D. J., Hamann, M., and Attwell, D. (2003). Multiple modes of GABAergic inhibition of rat cerebellar granule cells. J. Physiol. 548, 97-110. doi: 10 . 1113/jphysiol.2002.036459

Santhakumar, V., Meera, P., Karakossian, M. H., and Otis, T. S. (2013). A reinforcing circuit action of extrasynaptic GABAA receptor modulators on cerebellar granule cell inhibition. PLoS One 8:e72976. doi: 10.1371/journal.pone.007 2976

Schulman, J. A., and Bloom, F. E. (1981). Golgi cells of the cerebellum are inhibited by inferior olive activity. Brain Res. 210, 350-355. doi: 10.1016/00068993(81)90908-2

Simat, M., Parpan, F., and Fritschy, J. M. (2007). Heterogeneity of glycinergic and gabaergic interneurons in the granule cell layer of mouse cerebellum. J. Comp. Neurol. 500, 71-83. doi: 10.1002/cne.21142

Simões de Souza, F., and De Schutter, E. (2011). Robustness effect of gap junctions between Golgi cells on cerebellar cortex oscillations. Neural Syst. Circuits 7:7. doi: 10.1186/2042-1001-1-7

Solinas, S. M., Forti, L., Cesana, E., Mapelli, J., De Schutter, E., and D'angelo, E. (2007). Computational reconstruction of pacemaking and intrinsic electroresponsiveness in cerebellar Golgi cells. Front. Cell. Neurosci. 1:2. doi: 10. 3389/neuro.03.002.2007

Valenzuela, C. F., Lindquist, B., and Zamudio-Bulcock, P. A. (2010). A review of synaptic plasticity at Purkinje neurons with a focus on ethanol-induced cerebellar dysfunction. Int. Rev. Neurobiol. 91, 339-372. doi: 10.1016/s00747742(10)91011-8

Vos, B. P., Volny-Luraghi, A., and De Schutter, E. (1999). Cerebellar Golgi cells in the rat: receptive fields and timing of responses to facial stimulation. Eur. J. Neurosci. 11, 2621-2634. doi: 10.1046/j.1460-9568.1999.00678.x

Watanabe, D., and Nakanishi, S. (2003). mGluR2 postsynaptically senses granule cell inputs at Golgi cell synapses. Neuron 39, 821-829. doi: 10.1016/s08966273(03)00530-0

Xu, W., and Edgley, S. A. (2008). Climbing fibre-dependent changes in Golgi cell responses to peripheral stimulation. J. Physiol. 586, 4951-4959. doi: 10. 1113/jphysiol.2008.160879

Conflict of Interest Statement: The authors declare that the research was conducted in the absence of any commercial or financial relationships that could be construed as a potential conflict of interest.

Received: 11 November 2013; accepted: 16 January 2014; published online: 06 February 2014.

Citation: Botta P, Zucca A and Valenzuela CF (2014) Acute ethanol exposure inhibits silencing of cerebellar Golgi cell firing induced by granule cell axon input. Front. Integr. Neurosci. 8:10. doi: 10.3389/fnint.2014.00010

This article was submitted to the journal Frontiers in Integrative Neuroscience.

Copyright (c) 2014 Botta, Zucca and Valenzuela. This is an open-access article distributed under the terms of the Creative Commons Attribution License (CC BY). The use, distribution or reproduction in other forums is permitted, provided the original author(s) or licensor are credited and that the original publication in this journal is cited, in accordance with accepted academic practice. No use, distribution or reproduction is permitted which does not comply with these terms. 